УДК 368: 216

O. Bazilinska, O. Panchenko

\title{
ORGANIZATIONAL AND ECONOMIC FUNDAMENTALS OF COVERAGE OF RAILWAY
}

During the reformation of the railway and creation of its economic security, it is critical to study the organizational and economic fundamentals of the coverage of railway enterprises and define characteristic of formation of insurance relations between the railway enterprises and insurance companies. Improving the quality of insurance of the rail transport requires defining a legal framework regulating the coverage of railway enterprises, as well as presence of supervisory and control organisations that manage the implementation. Such organisations require a comprehensive application offinancial, economic and organizational methods of regulation of relations in the relationship "railway company-insurer". This study aims to disclose the organizational and economic fundamentals of the formation of the system of insurance protection of railway enterprises and to identify the areas for improvement in the process of activation of the reformation of the railway transport.

In order to achieve this goal, we outlined the characteristics of the formation of insurance relations between the railway and insurance companies and define the fundamental rules to be followed in the process of cooperation.

To ensure the implementation of the proposed railway insurance framework, we suggest to create an office for securing the rail transport, which, by using alternative methods, forms and presents a package of requirements for governing related services to a potential insurance company. We propose the main criterion for the selection of the foundation of the office to be the readiness to satisfy the needs of a transport operator and consider the implementation of an individual approach for providing insurance services.

Keywords: rail, railway insurance, risks, insurance company, insurance portfolio.

\section{JEL classification: G22, L91, L92}

\section{Introduction and Research Problem}

The process of reformation of the railway transport is aimed at the creation of conditions for increasing the efficiency of the railway in meeting the needs of the rail transportation. Consequently, of particular importance we see factors aimed at securing the transport process that support the improvement and increased competitiveness of rail transport in the transportation market and increase the quality of customer service.

The framework of the economic security of the railways has a significant impact on the development of the railway sector. The formation of the framework depends heavily on the management of the railway companies, the state of rolling stock and infrastructure, specifications of freight and passenger traffic, as well as the extent of the negative effects of incidents on the railway.

A powerful basis for creation of the economic security of railway companies is an effective system of the insurance protection, which includes the implementation of measures to prevent emergencies, as well as means to overcome consequences of such accidents and restore the transport process after their occurrence. The transfer of rail transportation to the insurance-based model entails the development of active cooperation between railway companies and insurance providers, that supports not only the best insurance protection and safety, but also improved decision-making in the area of the operation of the rail transport.

The reformation of the railway transport system requires creation of a legal framework for regulating rail security, as well as activities of organisations, which are responsible for supervision and control of the implementation. It is therefore necessary to define the organizational and economic fundamentals of the formation of insurance protection of railway companies, which describe a comprehensive application of financial, economic and organizational methods of regulation in the relationship "railway company - insurer" and the implementation of effective cooperation between designated entities to provide rail/freight security of the country. 
Hence, the study addresses an important topic of the need to enhance market-oriented reforms in the railway sector and insurance formation mechanism of the country's economic security in the process of integration into the European transport space.

Analysis of recent publications. Research of organizational and economic problems of many rail companies is conducted by a number of Ukrainian and foreign scientists, including Abramov A. P., Aksenov I. N., Belov I. V., Bogomolova N. I., Halaburda V. G., Ilchuk V. P., Kolesnikova N. M., Kochnev F. P., Kulayev Y. F., Makarenko M. V., Pasechnik V. I., Perepelyuk A. V., Pokotilov A. A., Sych E. M., Tryhunkov M. F., Tsvyetov Y. M., Shishkov A. P., and other prominent scientists.

The study of the formation of the system of insurance protection of enterprises in various areas of economic activity in the modern world is described in articles of numerous devoted scholars, such as Bazylevych V. D., Bihdash V. D., Vnukovo N. M., Hamankova O. O., Hovorushko T. A., Gorbach L. M., Mnyh M. V., Osadets S. S., Rotova T. A., Shumelda Y. P., as well as many others.

Unsolved parts of the problem. However, the process of reforming the railway and improving its economic security assumes a need to study the organizational and economic principles of risk insurance of railway companies and define characteristics of formation of the insurance in the "railway company - insurer" relationship, and in recognizing the importance of their activation for stimulation of development of rail transport.

Examination of research and development in the field of insurance coverage of transport companies shows the absence of works on the formation mechanism of insurance of railway companies. Hence the organizational and economic principles of insurance relationships that are formed for the coverage of rail traffic are not defined and the areas of improvement are not enumerated.

Aim and objectives of the research. The main aim of this article is to outline the organizational and economic principles of the formation of the system of insurance protection of railway companies and to identify areas of improvement in the revitalization of the reformation of the railway transport.

To achieve this aim, it is necessary to define features of formation of insurance relations between railway companies and insurance providers, as well as to formulate basic rules to be followed in the process their cooperation.

\section{Main findings}

The efficiency of rail transport is affected by the level of use of railway technical facilities and rolling stock, and the operational activity is based on strict adherence to safety and insurance of the reliability of transport, strict implementation of rules, regulations and processes, and clear interaction of all units and individual railway enterprises. The implementation of rail transportation is based on such variables as the schedule of trains, throughput and the freight capacity of the railway network, working and non-working fleets of locomotives in operation, as well as others. It demonstrates the need for organizational support for continuous and reliable operation of the railway transport, as well as creation of conditions for its insurance.

During the reformation of the railway the structure of management needs to be changed significantly. Therefore, it is advised to implement the decision-making process for the organization of insurance for the railway and definition of conditions for its implementation at the national level and at the level of railway enterprises. To implement this approach, the appropriate rights and resources for insurance coverage of passenger and freight transportation should be given to enterprises. And the responsibility for the maintenance of the base infrastructure and cooperation with the environment should remain on the state level, since the active cooperation of railway enterprises and insurance providers in the areas of insurance of railway transport and prevention of environmental risks is often limited by physically and morally outdated equipment and railway rolling stock.

So, a number of different models of cooperation between railway companies of different ownership and insurance providers may be used. Private railway operators have the right to choose the insurance company for supplying insurance contracts, and the state-owned operators may choose such providers during tenders. However, in any case the insurance relationship shall be regulated by the appropriate authorities. Figure 1 presents a scheme of the organization of insurance protection of railway transport (Fig. 1).

When building a framework of coverage of railway transport, one must provide:

- compliance of the organizational structure, qualifications and level of training of insurance companies with requirements of railway insurance;

- individual approach to the creation of contracts for providing insurance services of different objects of the railway; 


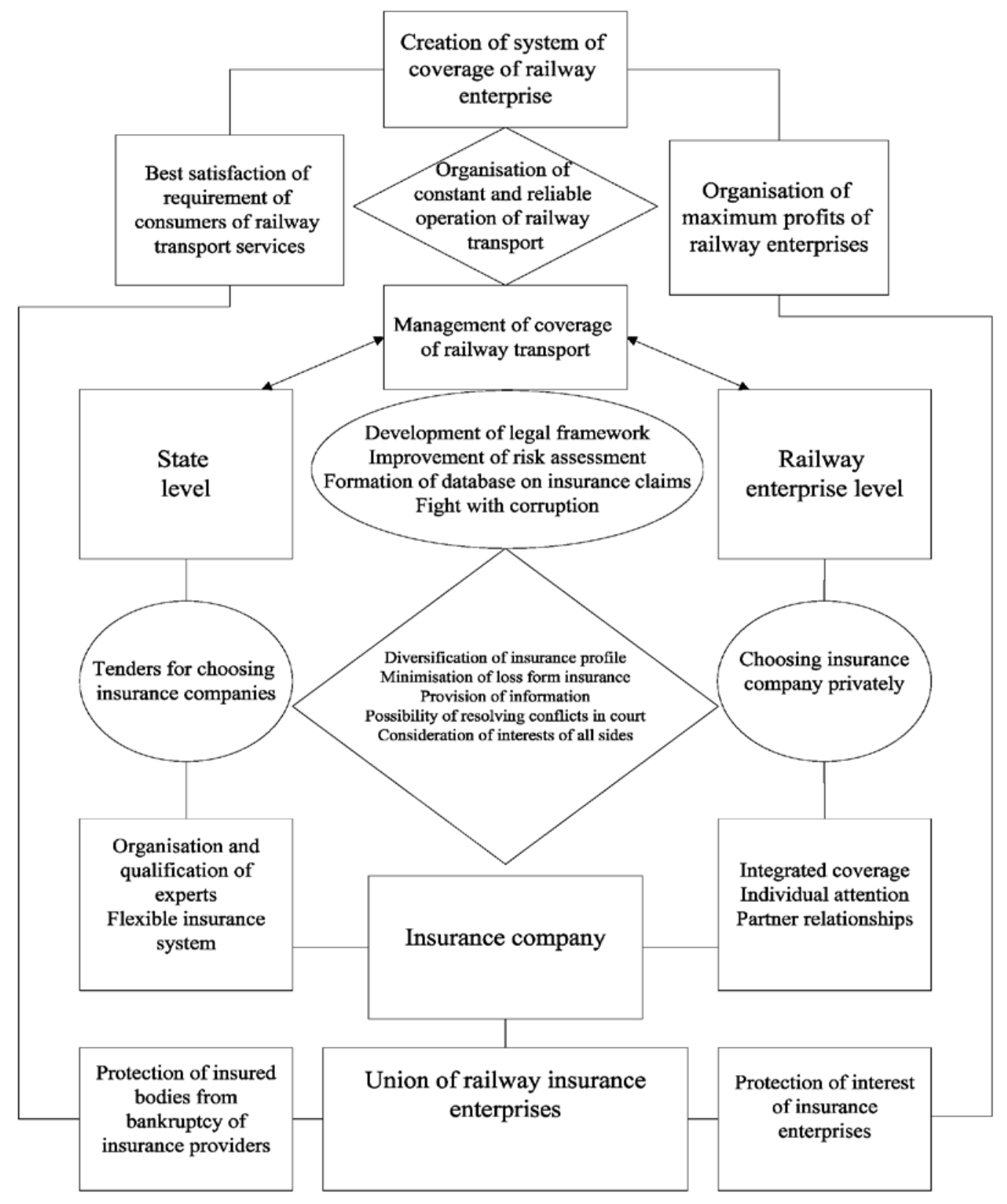

Fig. 1. Scheme of organisation of insurance coverage of rail security

- maximum flexibility of the system of insurance of facilities of railway transport;

- rational use of material and financial resources for the organization of insurance coverage;

- establishment of partnerships between parties of insurance contracts;

- comprehensive use of various means of insurance;

- primary organization of insurance protection of the most important objects.

An important condition for the cooperation is the existence of decent and qualified management in the insurance company. Such management must act in the interest of policyholders to facilitate the most complete protection possible and guarantee profes- sional claims handling. Therefore, during selection of potential insurers, of particular importance is the level of qualification of the specialists, as well as requirements for their competence and integrity.

In the process of organisation of the railway insurance framework, specific rules must be developed for each type of insurance, that are used to protect rail transportation. The consideration of specific factors must be undertaken in the event of unusual situations, the appearance of new objects or factors that affect the likelihood of insurance claims and the sizes of tariff rates. Consequently, the conditions of the contracts shall be formed based on the list of threats, importance, sizes (lengths) of 
objects, nature of the terrain, the existence of means of protection (alarm systems, automated control, accounting of real economic opportunities), type of protection utilised for a given object category, etc. Each object in rail insurance is characterized by its own specificity, and an individual approach needs to be used in the process of providing their security to deliver optimal conditions for the client.

Insurance companies that work with rail transport risks should build the best relationships with their customers by improving the insurance rules and taking into account the requirements of railway companies to avoid discrepancies between the insurer and the insured, and create conditions for the extension of contracts of insurance for another term.

It is also important to introduce foreign practices of organizing insurance for railway transport and, at the same time, accumulate our own insurance experience in improving the assessment of risks and losses caused by rail traffic accidents.

During the process of the settlement of losses problems occur even at the stage of submission of an application of the occurrence of an accident, in the case when an insurer refuses to accept documents and register the case, referring to formal reasons. At this stage, a risk that the accident will not be settled rises. Since the collection of all the necessary documents for registration of the application for insurance is limited by time, the railway company may lose the right to receive any insurance payments.

Consequently, insurance companies must have extensive networks of branches, which have the right to examine and settle losses, and to cooperate with international brokers with well-developed networks of representative offices abroad.

A railway company that has a role of an insured party or a beneficiary should consider its own insurance portfolio as a single management object and follow certain basic rules, such as:

1) in the process of formation of relationships with insurance companies, rail transport companies must consider all possible risks and place them based on the diversification. It is recommended to distribute the insurance portfolio of a railway company to three insurance companies, as follows:

- first company: insurance of railway business (insurance of rolling stock, cargo rail carrier liability, liability of the owner of a railway vehicle, etc.);

- second company: property insurance;

- third company: insurance of staff (insurance against accidents involving railway transport, life insurance, health insurance, etc.).
Additionally, others recommend to establish cooperation with only two insurance providers to increase flexibility and ensure efficiency in the management of the insurance portfolio of the railway company. Moreover, one such provider should be given more responsibilities, than the other provider;

2) to minimize the insurance costs, railway companies must keep track of statistics of loss on their own. The cost of insurance depends on the probability of the insured event, so continuous and uninterrupted account of insurance claims, applicable to rail insurance, may be used to reduce costs. After a defined period, such statistics will allow the assessment of losses and if the ratio of insurance payments and paid premiums will be below the acceptable level, the company may contact the insurance provider with reasonable proposal to lower the insurance rate.

The loss of insurance services in the area of railway insurance is affected by many factors. Typically, insurance rates and terms of insurance protection are designed to cooperate with railway companies, which have a long history of insurance protection, that have upgraded rolling stock equipped with modern technical facilities, with experiences staff.

The tariff policy of insurers that protect the rail transportation must quickly respond to the dynamics of loss, given the impact of many factors (statistics of insurance claims, dynamics of quotations for the repair of rolling stock, etc.). In addition, insurers are interested in working with companies that repair the railways, provide quality maintenance with low prices and reliable cooperation;

3) railway companies must exercise caution during the process of selecting insurance provides and consider the following:

- insurer must have a license for the required types of insurance;

- it is important to know which companies work with the insurer and what companies are the customers of the insurer;

- it is advised to learn the rules of insurance to determine your own requirements to be addressed in an offer for the insurer;

- the railway company must assess the solvency and ability of the insurer to make insurance payments by examining the financial statements of the insurer. An indicator of solvency and a rate of payments of the insurance provider may be calculated. Therefore, when choosing a potential insurance provider, a company also needs to have information on the activities of the company, namely the level of underwriting of risks, insurance of which it carries; 
the volume of insurance premiums and benefits; the financial condition of the insurer; financial resources to fulfil the obligations and compliance with the solvency margin; principles of conducting reinsurance; experience in rail and transport insurance;

4) in case of «railway company - insurer» during the process of formation of insurance relations, certain situations may arise, which involve making decisions about securing existing risks that require taking into account interests of other involved subjects. The conditions of insuring railway companies involve the possibility of insurance coverage of not only property that belongs to the companies, and is reflected in their balance sheets, but also of property taken as a loan, which was rented or leased. Basic and extended insurance contracts, as well as different approaches to insurance coverage, may be used for the formulation of insurance protection, depending on the type of property of the railway company.

Thus, for each company involved in the business of rail transport, an important way of purchasing the rolling stock and railway equipment is leasing or mortgaged loans. Typically, one of the conditions of the lease contract is insurance of the subject of the lease; thus the insurer also serves as the subject of insurance relations, and by also being a beneficiary (sometimes as well as an insured party) can significantly influence the choice of the insurance company and conditions of the insurance contract.

In the case of the rail company using the loan secured for the acquisition of railway vehicles, third party acts as a lender (beneficiary), which also collaborates with a select number of insurance companies and is interested to sign contracts with them to protect their own risks.

So, it is important to consider the interests of all parties of contractual relationships, as, otherwise, a risk of distributing the insurance portfolio among large number of insurers may arise. And, it may affect the premiums and the quality of the insurance protection. Therefore, in a railway company only one structural unit must manage all financial instruments (insurance, credits, leasing, etc.).

Therefore, railway companies should be aware of the need to develop and consolidate a number of new legal frameworks on the basis of the international practice of railway transport insurance, namely:

- adoption of regulations governing insurance of rail transport;

- improvement of licensing of railway insurance;

- implementation of this supervision of insurance companies that work with rail transportation;
- regulation of financial stability of insurers, who support the insurance on rail transport;

- improving the protection of the rights of policyholders, railway companies;

- methodological provision of rail insurance.

In today's insurance market environment, it is necessary to form a unified database of insurance history of the rail transportation to receive data on losses of each company, which can create more favourable conditions for insurance coverage for less unprofitable customers.

\section{Conclusions and Further Research Suggestions}

The improvement of the "railway company - the insurer" relationship plays a crucial role at the present stage of the development of insurance for the railway transport. The development of relations between railway companies and insurers should be based not only on changing and improving the rules of insurance protection of facilities and rail transportation, but also on the establishment of the rules of governance and the portfolio of an insurance provider.

Interactions between railway companies and insurance providers must be organised by the institution for securing rail transport, which can create and present a package of requirements governing relevant transportation to a potential insurance provider. The organisation can consider several alternatives during the preparation of the package of requirements. The main criterion for the selection the provider may be the readiness to satisfy the needs of a railway company and transport operator. However, all railway companies still face problems with customer dissatisfaction and receive complaints about the insurance coverage and the lack of consideration of the individual approach, when handling insurance claims.

Particular attention during the stage of implementation of insurance of railway companies should be given to the creation of an institution to protect the interests of policyholders in the rail insurance. Such an institution may be a part of the system of protection of consumers of the rail transport insurance, it may serve as a fund in the event of the bankruptcy of the insurer, which is replenished by contributions from all insurance companies engaged in the railway insurance. In some European countries insurance pools were created to facilitate better control and risk management in the railway transport. They support the development and expansion of the railway transport insurance. Participation in such associations is particularly important for insurers, which do not have enough experience in the area of railway insurance. 


\section{References}

1. Zakon Ukrainy "Pro zaliznychnyi transport" [The Law of Ukraine "On Railway Transport”]. (1996). Verkhovna Rada official web portal. Retrieved from http://zakon.rada.gov.ua/ cgi-bin/laws/main.cgi?nreg=273\%2F96-\%E2\%F0.

2. Zakon Ukrainy "Pro strakhuvannia" [The Law of Ukraine "On insurance"]. (1996). Verkhovna Rada official web portal. Retrieved from http://zakon.rada.gov.ua/cgi-bin/laws/main.cgi? nreg=85\%2F96-\%E2\%F0.

3. Zakon Ukrainy "Pro osoblyvosti utvorennia publichnoho aktsionernoho tovarystva zaliznychnoho transportu zahalnoho korystuvannia" [The Law of Ukraine "On peculiarities of the formation of a public company rail public transport"]. (2012). Verkhovna Rada official web portal. Retrived from http://zakon2. rada.gov.ua/laws/show/4442-17.

4. Postanova Kabinetu Ministriv Ukrainy "Pro zatverdzhennia Derzhavnoi tsilovoi prohramy reformuvannia zaliznychnoho transportu na 2010-2019 roky" [Act of KMU “On approval of the State Target Program of reforming the railway transport for 2010-2019 years"]. (2009, December 16). Verkhovna Rada official web portal. Retrived from http://zakon1.rada.gov.ua/ laws/show/1390-2009-\%D0\%BF.

5. Postanova Kabinetu Ministriv Ukrainy N 2174-r "Pro skhvalennia Transportnoi stratehii Ukrainy na period do 2020 roku" [Act of KMU No. 2174-r "On approval of the Transport Strategy of Ukraine till 2020"]. (2010, October 20). Retrieved from http://www.transport-ukraine.eu/sites/default/files/images/ transport_strategy_ua.pdf.

6. Kalambet, S. V., Yakymova, A. M., \& Horb V. A. (2011). Orhanizatsiino-ekonomichnyi mekhanizm vzaiemodii strakhovykh kompanii z pidpryiemstvamy v systemi zabezpechennia yikh finansovo-mainovoi bezpeky [Organizational-economic mechanism of interaction with enterprises of insurance companies are already providing their financial and property safety]. Investytsiyi: praktyka ta dosvid, 21, 14-17.

7. Panchenko, O. I. (2011). Strakhuvannia na zaliznychnomu transporti v umovakh yoho reformuvannia [Railways insurance in terms of its reform]. Zbirnyk naukovykh prats DETUT. Seriia «Ekonomika ta upravlinnia», 18, 51-57.

\section{Базілінська О. Я., Панченко О. I.}

\section{ОРГАНІЗАЦІЙНО-ЕКОНОМІЧНІ ЗАСАДИ СТРАХОВОГО ЗАХИСТУ ЗАЛІЗНИЧНОГО ТРАНСПОРТУ}

У проиесі реформування залізничного транспорту та створення системи його економічної безпеки актуальним є дослідження організаційно-економічних засад страхування ризиків залізничних підприємств та визначення особливостей формування страхових відносин між залізничними підприємствами та страховими компаніями. Удосконалення страхового забезпечення функціонування залізничного транспорту вимагає створення нормативно-правової бази регулювання залізничного страхування, а також органів нагляду та контролю за його реалізацією, щзо передбачає комплексне застосовування фінансово-економічних $і$ організачійних методів регулювання відносин у системі «залізничне підприємство - страховик». Тому це дослідження спрямоване на розкриття організачійно-економічних засад формування системи страхового захисту залізничних підприємств, а також визначення напрямів ії вдосконалення в процесі активізації реформування залізничного транспорту.

Для досягнення поставленої мети визначено особливості формування страхових відносин між підприсмствами залізничного транспорту та страховими компаніями, а також встановлено основні правила, яких необхідно дотримуватись у процесі організаиії співпрачі між ними.

Для забезпечення реалізачії залізничного страхування запропоновано створити Управління з убезпечення залізничного транспорту, яке на альтернативній основі формуватиме та пред'являтиме потенційній страховій компанії пакет вимог, щя регламентують відповідні послуги. Основним критерієм вибору є найкраще задоволення вимог транспортного оператора та врахування індивідуального підходу в процесі організаиії механізму страхування.

Ключові слова: залізничний транспорт, залізничне страхування, ризики, страхова компанія, страховий портфель. 